〈抄録〉第 24 回 日本臨床薬理学会年会 2003 年 12 月 $11 \sim 12$ 日 横浜 シンポジウム 7 : 治療薬による重篤な有害反応の予測・予防

\title{
1. Overview
}

中 野 眞 汎*

薬物投与により発生する有害な反応とその早期発 見・予防対策は重要な課題であり, 前年の第 23 回年会 では「治験中に報告される有害事象の取扱い」を取り 上げていただき，5名の専門家にそれぞれの立場から問 題提起をしていただいた（臨床薬理 2003; 34(3): 457S468S)，今回は日常の薬物療法中に起きる有害薬物反応 を取り上げたい．これらの有害反応は，常用量を超え て処方したという訳でもないのに起こるので，その原 因を突き止めることが肝要である.

原因としては以下の場合が考えられ，これらの場合 には常用量投与なのに血中薬物濃度が毒性発現濃度域 へ上昇する例である。

\section{常用量投与で血中薬物濃度が上がる場合}

・その患者の代謝能が遺伝的に弱い

・臓器疾患の結果, 代謝能が弱まった

・臓器疾患の結果, 排泄能が弱まった

・加㱓により代謝・排泄能が低下した

・併用薬物が代謝酵素を阻害した

・併用薬物が代謝酵素を競合し相互の薬物の代謝速度 を低下した

・併用薬物が排泄トランスポーターを競合し相互の薬 物の排泄速度を低下した

常用量投与でも，連続投与により血中薬物濃度が上 昇する可能性を顧みないと, 以下のような例も起こり うるので, 薬物療法中には患者の観察が求められる. 早めに発見すれば重症化を防げられたと反省するし, さらに進めて，原因を解明できれば以後の予防が検討 しやすくなる.
患者観察が遅れると起こりうるケース

・外来治療中に有害薬物反応がひどくなり入院加療が 強いられた場合

- 入院薬物治療中に有害反応が現れ, 入院期間延長と なった場合

その他に投与薬物量と関係なく，ある種の薬物に異 常に敏感な患者がおり，この場合には反応を予測しに くいので, 因子の解明が求められる (過敏症).

そこで, 薬物療法に関与する医師・薬骫師・看護師 は有害薬物反応につき，より一層知るべきであり，患 者へも伝えるべき時代となっている.

広く知らせるためのネット利用

アメリカでは有害薬物反応に対する意識付けのため に, FDAも支援して, 'Preventable adverse drug reactions’をネット上に紹介し誰でも見れる環境を整 備している.

今回のシンポジウム

・日医大多摩永山病院の新先生に QT 延長

-千葉大の千葉先生に横紋筋融解症と代謝酵素多形の 関係

- 昭和大学皮膚科飯島先生にStevens-Johnson 症候群 など

・埼玉医大安藤先生には抗癌薬による有害反応とグル クロン酸抱合酵素活性個体差など

・福岡の大澤先生には有害薬物反応早期発見のための 病棟での薬剂師活動

を紹介していただく.

$*$ 静岡県立大学大学院薬学研究科臨床薬剤学

干 422-8526 静岡市谷田 52-1 